\title{
For mange tidsskrifter - for lite god forskning
}

Jeg sendte mitt første manuskript til et internasjonalt vitenskapelig tidsskrift i 1998. Den gang var det vanlig at manuskripter var «på vandring». Det innebar at når et manus ble refusert av ett tidsskrift, ble det sendt videre til et annet, gjerne med litt lavere prestisje enn det første man hadde forsøkt seg på. Når så refusjonen kom også fra det andre tidsskriftet, ble manuset sendt videre til et tredje. Mens denne prosessen pågikk, ventet man. Forskeres venting på respons fra tidsskriftredaktører var velkjent. Mye tid og frustrasjon gikk med til dette. Men det som for utenforstående kunne se ut som meningsløs aktivitet, var likevel ikke bare det. Ofte var manuset blitt vurdert av eksterne fagvurderere, og dermed fikk man gode råd om hvordan det kunne forbedres.

De siste årene er dette endret. Fortsatt kan man selvsagt få sine manus i retur hvis man sender inn til de mest prestisjefylte tidsskriftene. Men manus trenger ikke legge ut på vandring slik som tidligere. Én forklaring på dette er fremveksten av en mengde nye elektroniske tidsskrifter. Bare BioMed Central, som ble grunnlagt i 2000, tilbyr nå mer enn 220 ulike tidsskrifter (1). Hvis jeg hadde gjort en middelmådig studie, ville jeg sendt manuset til et slikt tidsskrift. Jeg har ennå til gode å bli refusert. Jeg har inntrykk av at dersom manuset har et minstemål av kvalitet, blir det akseptert for publisering. Til å begynne med var gleden stor over å slippe å få manus ut på vandring. Det var deilig å kunne sende inn et manus og regne med at det ble akseptert. Jeg har nevnt dette for kolleger i ulike miljøer. Mange av dem har ikke reflektert over det. «Jo, når du sier det, jeg har faktisk heller aldri fått manus refusert i slike tidsskrifter,» er gjerne responsen. Det er ikke nødvendigvis dårlige tidsskrifter, de har ordinær ekstern fagfellevurdering, de blir indeksert $\mathrm{i}$ de sentrale databasene og er fritt tilgjengelig på nettet. Er det da noe problem?

Én grunn til at man i disse tidsskriftene aksepterer mange manus, er publiseringsformen. Artiklene publiseres kun på Internett, og i cyberspace er som kjent plassen nærmest ubegrenset og publiseringskostnadene nesten null. Verken antall artikler eller antall sider bekymrer redaktører og utgivere. Her er rom for alt. Problemet er at antall gode studier og antall gode manus ikke har økt i samme takt. Resultat: Mye forskning som verken er spesielt god eller spesielt viktig blir publisert.

I de fremste vitenskapelige tidsskriftene er det fortsatt en sentral oppgave for redaktørene å publisere de beste og mest banebrytende studiene. Dem er det få av. Det er kamp mellom redaksjonene for å kapre de virkelig gode artiklene. Redaktører oppsøker forskere på kongresser og faglige møter og forsøker å få dem til å sende det ypperste til nettopp dem. «Editing is all about personal relationships,» sa en redaktørkollega i et stort amerikansk tidsskrift til meg nylig. Det gjelder å være både proaktiv og aggressiv for å få tak i «the really good papers», sa han. Drivkraften er selvsagt at dersom tidsskriftet publiserer slike artikler, vil det tiltrekke seg flere lesere, få flere siteringer, høyere impaktfaktor - og mer penger (2). Hvilken redaktør kan da motstå fristelsen til å ta litt lett på det? Hvis studien er stor og viktig, vil man kanskje også tilby «fast track publication». Da vil tidsskriftet garantere publisering innen for eksempel fire uker etter at manuset er mottatt i redaksjonen (3). Det er en åpenbar fare for at den faglige kvalitetssikringen da blir dårligere enn ellers. Det var kanskje ikke bare tilfeldig at artikkelen som avslørte Jon Sudbøs svindel, nettopp hadde gått ekstra raskt igjennom (4).

Disse to fenomenene, at det er enklere å publisere enn det var før og at kvalitetskontrollen er under press, skaper nye utfordringer. Det er blitt lettere for dem som skal publisere, men vanskeligere for dem som skal bruke forskningen. Hvordan kan man vite at en studie både er kvalitativt god og viktig? Bare i PubMed, den viktigste biomedisinske databasen, er det indeksert over 5500 tidsskrifter (5) og 21 millioner artikler (6), og gjennomsnittlig indekseres det en ny artikkel hvert minutt (7). Kampen for å henge med faglig, enten man er forsker eller kliniker, er formidabel og uoverkommelig, sies det gjerne. Etter min mening er det ikke slik. Det aller meste av det som publiseres, kan trygt overses. Forskerne burde kanskje ha droppet prosjektet og heller brukt sine hardt tiltrengte ressurser på studier som virkelig trengs. Når jeg leser kunnskapsoppsummeringer eller oversiktsartikler, blir jeg oftere slått av kunnskapsmangelen enn av det motsatte.

Tidsskrifter som tjener sine penger ved å kreve betaling av forfatterne, slik som mange av de nye elektroniske tidsskriftene gjør, vil tjene mer jo flere artikler som publiseres. Forskerne vil tjene mer, i form av forfremmelser, forskningsstøtte og uttelling fra tellekantsystemet, dersom de publiserer mye. Det kan dermed lønne seg både for forskere og redaktører å publisere mange middelmådige studier fremfor færre gode. Kanskje er det bra for tidsskriftenes økonomi og forskernes karrierer, men det spørs om det er nyttig for særlig mange flere.

\section{Erlend Hem}

erlend.hem@medisin.uio.no

Erlend Hem (f. 1970) er dr.med. og assisterende redaktør i Tidsskriftet.

\footnotetext{
Litteratur

. The BioMed Central: the open access publisher. www.biomedcentral.com (12.8.2011).

2. Haug C. Profittkarusellen. Tidsskr Nor Lægeforen 2007; 127: 1173.

3. The Lancet. Fast-track publication. www.thelancet.com/ lancet-information-for-authors/fast-track (12.8.2011).

4. Sudbø J, Lee JJ, Lippman SM et al. Non-steroidal anti-inflammatory drugs and the risk of oral cancer: a nested case-control study. Lancet 2005: 366 : 1359-66. Tilbaketrekking: Horton R. Lancet 2006; 367: 382.

5. The National Library of Medicine. Number of titles currently indexed for Index Medicus and MEDLINE on PubMed.www.nlm.nih.gov/bsd/num_titles.html (12.8.2011).

6. PubMed. www.ncbi.nlm.nih.gov/sites/entrez?db=pubmed\&cmd=search\&term= 1800: 2100[dp] (12.8.2011).

7. How many journal articles have been published (ever)? I: O'Really? Duncan Hull blogg 15.7.2010. http://duncan.hull.name/2010/07/15/fifty-million (12.8.2011).
} 